\title{
PENGARUH PERAN KEPEMIMPINAN DAN BUDAYA ORGANISASITERHADAP MOTIVASI KERJA YANG BERDAMPAK PADA PENINGKATAN KINERJA PERANGKAT DESA DI KECAMATAN TELUKJAMBE TIMUR
}

\author{
Anirah \\ Anirah77@yahoo.com \\ Universitas Singaperbangsa Karawang
}

\begin{abstract}
This research aims to obtain empirical evidence and find clarity of phenomena and conclusions about the influence of leadership roles and organizational culture on work motivation that impact on improving the performance of Village Devices District of East Telukjambe.

This thesis is expected to contribute to the development of management science, especially as a contribution of scientific literature in human resources management, as reference material in scientific writing, as information material, both for leaders and colleagues in Kecamatan Telukjambe Timur Karawang regency in the implementation of performance based management, as a material consideration and input in making decisions and determine the direction of policy.

The research is done by using quantitative method with descriptive and verification method, that is collecting, presenting, analyzing and doing hypothesis testing, and making conclusion and suggestion.

Based on the results of the research analysis, the following conclusions are obtained: The value of correlation coefficient between leadership variables and organizational culture is 0.595 , Influence of leadership role to employee work motivation equal to 0,1616 or $16,16 \%$. The influence of organizational culture on employee work motivation of 0.2504 or $25.04 \%$. The influence of leadership role on employee performance is 0.0723 or $7.23 \%$. While the influence of organizational culture on employee performance of 0.0230 or $2.30 \%$. The influence of work motivation on employee performance of 0.7448 or $74.48 \%$. Simultaneously the role of leadership and organizational culture significantly influence the work motivation of $41.20 \%$. The rest of $58.80 \%$ is the influence that comes from other factors. Simultaneously the role of leadership and organizational culture has a significant effect on work motivation which impact on employee performance improvement equal to $84,01 \%$. The rest of $15.99 \%$ is the influence that comes from other factors.
\end{abstract}

Keywords: role of leadership, organizational culture, work motivation, employee performance

\section{Latar Belakang}

Organisasi merupakan kesatuan sosial yang dikoordinasikan secara sadar dengan sebuah batasan yang reaktif dapat diidentifikasikan, bekerja secara terus menerus untuk mencapai tujuan. Kemudian menurut Euis Sholeha dan Suzy mengemukakan organisasi adalah perserikatan orang-orangyang usahanya harus dikoordinasikan, tersusun dari sejumlah sub system yang saling berhubungan dan 
saling tergantung, bekerja sama atas dasar pembagiankerja, peran dan wewenang, serta mempunyai tujuan tertentu yang hendak dicapai. Dalam mencapai tujuan organisasi, setiap organisasi memerlukan sumber daya untuk mencapainya. Sumber daya merupakan sumber energi,tenaga, kekuatan yang diperlukan untuk menciptakan aktivitas ataupunkegiatan. Sumber daya itu antara lain sumber daya alam, sumber dayafinansial, sumber daya ilmu pengetahuan dan teknologi, serta sumber dayamanusia. Diantara sumber daya tersebut, sumber daya yang terpenting ialahsumber daya manusia. Sumber daya manusia dianggap penting karena dapatmempengaruhi efisiensi dan efektivitas organisasi, serta merupakan pengeluaran pokok organisasi dalam menjalankan kegiatannya.Sumber daya manusia yaitu sumber daya yang digunakan untuk menggerakkan, dan mensinergikan sumber daya lainnya untuk mencapaitujuan organisasi.

Secara teoritis, bahwa kinerja pegawai sangat dipengaruhi oleh banyak hal, antara lain seperti peran kepemimpinan, budaya organisasidan motivasi kerja yang dilakukan oleh atasan dalam lingkungan kerja. Hal tersebut yang mendasari sebuah organisasi harus bisa lebih mementingkan dalam upaya melakukan pembenahan agar mampu mencapai target sesuai dengan apa yang diharapkan. Pembenahan dalam sekup organisasi selain di organisasi swasta, juga diperlukan diorganisasi yang bersifat pemerintahan. Karena pemerintahan yang efektif tergantung pada personal yang menggerakannya, dalam hal ini terletak pada kinerja seluruh aparatur pemerintahan yang bertugas ditingkat pusat, daerah sampai desa. Dan salah satunya adalah pemerintahan pada Kecamatan Telukjambe Timur Kabupaten Karawang.

Seorang pemimpin adalah orang yang memberi inspirasi, membujuk, mempengaruhi, dan memotivasi kerja orang lain. Kemampuan untuk memberi inspirasi orang lain adalah unsur tertinggi dari kepemimpinan. Seorang pemimpin harus punya daya tarik personal atau menjadi suri tauladan agar bisa memberi inspirasi bagi orang lain. Membujuk adalah aspek penting lainnya dari seorang pemimpin. Seorang pemimpin harus bisa mengubah pikiran bawahannya atau bertindak tegas (Dubrin,2009:10-11).

Motivasi kerja perangkat desa paling tinggi jawaban responden sebanyak 39 orang hal tersebut menandakan bahwa kurangnya motivasi bagi perangkat desa dalam melakukan pekerjaan yang disebabkan oleh pola atau peran pemimpin yang dilakukan di lingkungan desa tidak sesuai dengan apa yang diharapkan oleh perangkat desa itu sendiri, karena pemimpin adalah orang yang bisa serta mampu mengayomi para bahawan ketika melakukan pekerjaan. Dan jawaban tertinggi kedua adalah peran kepemimpinan, dari grafik di atas sebanyak 36 orang menyatakan bahwa peran pemimpin yang ada sekarang ini kurang bisa diandalkan dikarenakan sistim pola kerja yang salah. Hal tersebut tentunya bawahan merasakan adanya komunikasi yang terputus dengan atasan sehingga mereka menyatakan bahwa kepemimpinan yang ada di setiap desa Kecamatan Telukjambe Timur tidak dilakukan sesuai dengan standar baku yang telah ditetapkan oleh Kecamatan. Padahal kepemimpinan bisa memberikan dorongan/motivasi kerja kepada pegawai dalam peningkatan kinerja pegawai.

Penelitian ini bertujuan untuk mengkaji Pengaruh Peran Kepemimpinan Dan Budaya Organisasi Terhadap Motivasi KerjaYang Berdampak Pada 
Penngkatan Kinerja Perangkat Desa Di Kecamatan Telukjambe Timur Kabupaten Karawang.

\section{Perumusan Masalah}

Berdasarkan latar belakang diatas terdapat perumusan masalah yang diambil, yaitu :

1. Bagaimana peran kepemimpinan Kecamatan Telukjambe Timur?

2. Bagaimana Budaya Organisasi Kecamatan Telukjambe Timur?

3. Bagaimana Motivasi Kerja perangkat desa Kecamatan Telukjambe Timur ?

4. Bagaimana kinerja perangkat desa Kecamatan Telukjambe Timur?

5. Seberapa besar korelasi antara Kepemimpinan dan Budaya Organisasi perangkat desa Kecamatan Telukjambe Timur?

6. Seberapa besar pengaruh parsial kepemimpinan dan budaya organisasi terhadap motivasi kerja perangkat desa Kecamatan Telukjambe Timur ?

7. Seberapa besar pengaruh secara simultan Kepemimpinan dan budaya organisasi terhadap motivasi kerja perangkat desa Kecamatan Telukjambe Timur?

8. Seberapa besar pengaruh motivasi kerja terhadap kinerja perangkat desa Kecamatan Telukjambe Timur?

\section{Kepemimpinan}

Definisi kepemimpinan menurut Howard H. Hoyt yang dikutip oleh Kartono (2008:57) adalah kegiatan atau seni mempengaruhi orang lain agar mau bekerjasama yang didasarkan pada kemampuan orang tersebut untuk membimbing orang lain dalam mencapai tujuan-tujuan yang diinginkan kelompok. Kepemimpinan menurut Anaroga yang dikutp oleh Edy Sutisna (2011:214) bahwa kepemimpinan adalah kemampuan untuk mempengaruhi pihak lain, melalui komunikasi baik langsung maupun tidak langsung dengan maksud menggerakan orang-orang agar dengan penuh pengertian, kesadaran dan senang hati bersedia mengikuti kehendak pimpinan itu. Dapat disimpulkan bahwa kepemimpinan merupakan kemampuan mempengaruhi orang lain, bawahan atau kelompok, kemampuan mengarahkan tingkah laku bawahan atau kelompok, memiliki kemampuan atau keahlian khusus dalam bidang yang diinginkan oleh kelompoknya, untuk mencapai tujuan organisasi atau kelompok.

\section{Dimensi dan Indikator Kepemimpinan}

Berikut ini adalah dimensi dan indikator kepemimpinan yang dijadikan sebagai acuan dalama penelitian ini. Menurut umairi (2009) dimensi dan indikator kepemimpinan yaitu:

a. Kepribadian, indikatornya adalah : memiliki kreativitas dan menjadi teladan

b. Peranan, indikatornya adalah : menjalankan visi dan misi, mengembangkan metode kerja baru, melakukan pengawasan dan evaluasi.

c. Organisasi, yaitu : memberikan motivasi, melakukan pendelegasian wewenang, memberikan penghargaan, memberikan diklat, memberikan beasiswa, hubungan dengan bahwan, memfasilitasi kebutuhan pegawai dan tanggap aspirasi pegawai.

d. Tugas, indikatornya adalah membuat keputusan dengan cepat dan tepat serta memberikan pengarahan. 


\section{Budaya Organisasi}

Menurut Kotter dan Heskett (2010) budaya organisasi adalah nilai dan praktik yang dimiliki bersama seluruh kelompok dalam suatu organisasi, sekurangkurangnya dalam manajemen senior. Budaya organisasi dapat dilihat dalam dua tingkat, yaitu yang terlihat dalam permukaan, yang umumnya menyangkut perilaku dan sikap-sikap dalam hubungan dengan benda-benda fisik dan yang lebih dalam lagi menyangkut nilai-nilai yang dianut bersama. Sedangkan Robbins dan Coulter (2009, p58) mendefisinikan budaya organisasi sebagai suatu sistem makna bersama yang dianut oleh anggota organisasi yang menentukan, sebagaian besar cara mereka bertindak. Menurut Umar ( 2008, p.207 ) budaya organisasi adalah suatu sistem nilai dan keyakinan besama yang diambil dari pola kebiasaan dan falsafah dasar pendiriannya yang kemudian berinteraksi menjadi normanorma, dimana norma tersebut dipakai sebagai pedoman cara berpikir dan bertindak dalam upaya mencapai tujuan bersama. Dengan mendasarkan berbagai definisi di atas, maka dapat disimpulkan bahwa budaya organisasi adalah suatu sistem nilai yang diyakini bersama yang berasal dari falsafah atauprinsip awal pendirian organisasi kemudian berinteraksi menjadi norma-norma, yang dijadikan sebagai pedoman untuk mencapai tujuan organisasi.

\section{Dimensi dan Indikator Budaya Organisasi}

Menurut Robbins dalam Tika (2008:10) komponen dari budaya organisasimemiliki dimensi dan indikator sebagai berikut:

1. Inisiatif, indikatornya adalah menghasilkan ide, tindakan dan solusi inovatif serta mengantisifasi dan memahami masalah yang mungkin akan terjadi.

2. Toleransi terhadap resiko, indikatornya adalah : berani mengambil resiko atas pekerjaan dan agresif serta inovatif dalam mengambil resiko atas pekerjaan.

3. Arah, indikatornya adalah visi dan misi yang jelas dan standar serta tujuan kerja yang realistis

4. Integrasi, indikatornya adalah : upaya organisasi terhadap terciptanya koordinasi antar unit kerja dan komitmen pegawai terhadap organisasi

5. Dukungan organisasi, indikatornya adalah : dorongan kepada pegawai untuk mengembangkan diri dan memberikan masukan yang tepat.

6. Kontrol, indikatornya adalah pembuatan laporan dan monitor dan evaluasi pekerjaan

7. Identitas, indikatornya adalah identitas pegawai dalam organisasi.

8. Imbalan, indikatornya adalah alokasi imbalan sesuai jabatan dan alokasi imbalan sesuai prestasi.

9. Toleransi terhadap konflik, indikatornya adalah pegawai didorong untuk mengemukakan konflik secara terbuka dan pegawai didorong untuk mengemukakan kritik secara terbuka.

10. Pola-pola komunikasi, indikatornya adalah komunikasi vertikal dan komunikasi horizontal.

\section{Motivasi}

Motivasi Karyawan menurut Winardi (2009), motivasi berasal dari kata motivation yang berarti "menggerakkan". Motivasi merupakan hasil sejumlah proses yang bersifat internal atau eksternal bagi seorang individu, yang 
menyebabkan timbulnya sikap entutiasme dan persistensi dalam hal melaksanakan kegiatan-kegiatan tertentu. Sedangkan motivasi kerja adalah suatu kekuatan potensial yang ada dalam diri seorang manusia, yang dapat dikembangkannya sendiri atau dikembangkan oleh sejumlah kekuatan luar yang pada intinya berkisar sekitar imbalan moneter dan nonmoneter, yang dapat mempengaruhi hasil kinerjannya secara positif atau secara negatif, hal mana tergantung pada situasi dan kondisi yang dihadapi orang yang bersangkutan.

Menurut A. Anwar Prabu Mangkunegara, memberikan pengertian motivasi dengan kondisi yang berpengaruh membangkitkan, mengarahkan dan memelihara prilaku yang berubungan dengan lingkungan kerja. Menurut $\mathrm{H}$. Hadari Nawawi mendefinisikan motivasi sebagai suatu keadaan yang mendorong atau menjadi sebab seseorang melakukan sesuatu perbuatan atau kegiatan yang berlangsung secara sadar. Menurut Henry Simamora, pengertian motivasi menurutnya adalah Sebuah fungsi dari pengharapan individu bahwa upaya tertentu akan menghasilkan tingkat kinerja yang pada gilirannya akan membuahkan imbalan atau hasil yang dikehendaki. Menurut Soemanto secara umum mendefinisikan motivasi sebagai suatu perubahan tenaga yang ditandai oleh dorongan efektif dan reaksi- reaksi pencapaian tujuan. Karena kelakuan manusia itu selalu bertujuan, kita dapat menyimpulkan bahwa perubahan tenaga yang memberi kekuatan bagi tingkahlaku mencapai tujuan,telah terjadi di dalam diri seseorang.

Dari pengertian-pengertian motivasi diatas maka dapat disimpulkan bahwa motivasi merupakan suatu keadaan atau kondisi yang mendorong, merangsang atau menggerakan seseorang untuk melakukan sesuatu atau kegiatan yang dilakukannya sehingga ia dapat mencapai tujuannya.

\section{Dimensi dan Indikator Motivasi}

Berikut ini adalah dimensi dan indikator motivasi McClelland (Veirtzal Rivai, 2011) yang dijadikan sebagai acuan dalam dalam penelitian ini :

a. Kebutuhan berprestasi (Need for achievement), yang meliputi indikator berusaha melakukan sesuatu dengan cara baru dan kreatif, mencari feedback tentang perbuatannya, memilih resiko yang sedang dalam perbuatannya, mengambil tanggung jawab pribadi atas perbuatannya.

b. Kebutuhan berafiliasi (Need for affiliation), indikatornya adalah : menyukai persahabatan, mencari persetujuan atau kesepakatan dari orang lain, lebih suka bekerja sama daripada berkompetisi dan selalu berusaha menghindari konflik.

c. Kebutuhan untuk menguasai sesuatu (Need for power), indikatornya adalah menyukai pekerjaan dimana dia menjadi pemimpin, sangat aktif dalam menentukan arah kegiatan dari sebuah organisasi dimanapun dia berada dan senang dengan tugas yang dibebankan kepadanya.

\section{Kinerja}

Menurut Mangkunegara (2011), kinerja atau prestasi kerja adalah hasil kerja kualitas dan kuantitas yang dicapai oleh seorang pegawai dalam melaksanakan tugasnya sesuai dengan tanggung jawab yang diberikan kepadanya. Sedangkan menurut Gibson et.al. (2008:123-124) kinerja karyawan merupakan suatu ukuran yang dapat digunakan untuk menetapkan perbandingan 
hasil pelaksanaan tugas, tanggung jawab yang diberikan oleh organisasi pada periode tertentu dan relatif dapat digunakan untuk mengukur prestasi kerja atau kinerja organisasi. Menurut Veithzal yang dikutip dalam Suwatno dan Donni Juni (2011:196), kata kinerja merupakan terjemahan dari kata performance yang berasal dari kata to perform dengan beberapa entries;1) melakukan, menjalankan, melaksanakan (to do or carry out, execute), 2) memenuhi atau melaksanakan kewajiban suatu niat atau nazar (to discharge of fulfil; as vow), 3) melaksanakan atau menyempurnakan tanggung jawab (to execute or complete dan 4) melakukan sesuatu yang diharapkan oleh orang atau mesin (to do what is expected of a person machine).

\section{Dimensi dan Indikator Kinerja}

Menurut (Gomez dalam Mangkunegara, 2009:42)dimensi dari variabel kinerja karyawan adalah :

1. Kualitas hasil pekerjaan, memiliki indikator :ketepatan waktu, ketelitian kerja, dan kerapian kerja

2. Kuantitas hasil pekerjaan, indikatornya adalah jumlah pekerjaan dan jumlah waktu yang dibutuhkan.

3. Pengertian terhadap pekerjaan, indikatornya adalah pemahaman terhadap pekerjaan dan kemampuan kerja

4. Kerja sama, indikatornya adalah kemampuan bekerja sama.

5. Kreatifitas, Merupakan kemampuan seorang pegawai dalam menyelesaikan pekerjaannya dengan cara atau inisiatif sendiri yang dianggap mampu secara efektif dan efisien serta mampu menciptakan perubahan-perubahan baru guna perbaikan dan kemajuan organisasi.

6. Kesadaran indikatornya adalah disiplin, tepat waktu dan kerja sama

7. Pengetahuan tentang pekerjaan, indikatornya adalah pendidikan, pengalaman dan lingkungan pekerjaan

8. InisiatifMelingkupi beberapa aspek seperti kemampuan untuk mengambil langkah yang tepat dalam menghadapi kesulitan, kemampuan untuk melakukan sesuatu pekerjaan tanpa bantuan, kemampuan untuk mengambil tahapan pertama dalam kegiatan.

9. Kualitas pribadi, indikatornya adalah menyangkut kepribadian, kepemimpinan, keramahtamahan dan integrasi pribadi.

\section{Metode yang digunakan}

Setiap penelitian mempunyai tujuan dan kegunaan tertentu. Metoda yang digunakan dalam penelitian ini adalah metode deskriptif yaitu metoda damal meneliti status kelompok manusia, suatu objek, suatu set kondisi, suatu sistem pemikiran atau kelas peristiwa pada masa sekarang. Tujuannya adalah membuat gambaran atau lukisan secara sistematis, faktual dan akurat. Berdasarkan latar belakang masalah yang ada, karakteristik masalah yang diteliti dalam penelitian ini dapat diklasifikasikan sebagai penelitian eksplanatory yaitu penelitian untuk menguji hubungan antar variabel yang dihipotesiskan. Pada penelitian ini jelas ada hipotesis yang akan diuji kebenarannya.

\section{Disain Penelitian}


Suharsimi Arikunto (2010:90) mengemukakan bahwa "Desain penelitian adalah rencana atau rancangan yang dibuat oleh peneliti, sebagai rancangan kegiatan yang akan dilaksanakan." Desain penelitian juga dapat diartikan sebagai rencana struktur, dan strategi. Sebagai rencana dan struktur, desain penelitian merupakan perencanaan penelitian, yaitu penjelasan secara rinci tentang keseluruhan rencana penelitian mulai dari perumusan masalah, tujuan, gambaran hubungan antar variabel, perumusan hipotesis sampai rancangan analisis data, yang dituangkan secara tertulis ke dalam bentuk usulan atau proposal penelitian. Sebagai strategi, desain penelitian merupakan penjelasan rinci tentang apa yang akan dilakukan peneliti dalam rangka pelaksanaan penelitian.

\section{Variabel Penelitian}

Variabel Penelitian adalah suatu atribut atau sifat atau nilai dari orang, obyek atau kegiatan yang mempunyai variasi tertentu yang ditetapkan oleh peneliti untuk mempelajari dan kemudian ditarik kesimpulannya. dilihat dari hubungan variabel satu dengan variabel yang lain, maka macam-macam variabel dalam penelitian dibedakan menjadi Variabel independent, Variabel dependen, Variabel moderator, Variabel intervening, Variabel control. Penelitian ini menggunakan empat variabel yaitu dua variabel bebas $\mathrm{X}_{1}$ dan $\mathrm{X}_{2}$, satu variabel intervening $(\mathrm{Z})$ dan satu variabel terikat $(\mathrm{Y})$. Dalam hal ini variabel $\mathrm{X}_{1}$ adalah kepemimpinan, variabel $\mathrm{X}_{2}$ adalah budaya organisasi dan $\mathrm{Z}$ adalah motivasi merupakan variabel yang mempengaruhi variabel $\mathrm{Y}$ yaitu kinerja perangkat desa di Kecamatan Telukjambe Timur. Dalam penelitian ini akan dijelaskan variabel utama yang akan digunakan dalam penelitian, sub variabel dan indikator yang dijadikan bahan pengukuran sebagai berikut:

\section{Sumber Data}

Yang dimaksud dengan sumber data dalam penelitian adalah subyek dari mana data dapat diperoleh. Dalam penelitian ini penulis menggunakan dua sumber data yaitu :

a. Sumber data primer, yaitu data yang langsung dikumpulkan oleh peneliti (atau petugasnya) dari sumber pertamanya. Adapun yang menjadi sumber data primer dalam penelitian ini adalah Perangkat Desa di Kecamatan Telukjambe Timur.

b. Sumber data skunder, yaitu data yang langsung dikumpulkan oleh peneliti sebagai penunjang dari sumber pertama. Dapat juga dikatakan data yang tersusun dalam bentuk dokumen-dokumen.Dalam penelitian ini, dokumentasi dan angket merupakan sumber data sekunder.

\section{Populasi, Sampel Dan Teknik Sampling}

Menurut Sugiyono (2013:80) populasi adalah wilayah generalisasi yang terdiri atas obyek/subyek yang mempunyai kualitas dan karakteristik tertentu yang ditetapkan oleh peneliti untuk dipelajari dan kemudian ditarik kesimpulannya. Jadi populasi bukan hanya orang, tetapi juga obyek dan benda-benda alam yang lain. Hal ini sejalan dengan pendapat Emory dalam Assegaf (2009) yang menyatakan populasi merupakan sekumpulan elemen yang dapat digunakan untuk beberapa kesimpulan. Dengan demikian populasi dalam penelitian ini adalah 
seluruh aparat desa yang bekerja di Kecamatan Telukjambe Timur yang berjumlah 100 orang.

Selanjutnya menurut Sugiyono (2013:81) menjelaskan sampel adalah bagian dari jumlah dan karakteristik yang dimiliki oleh populasi tersebut. Bila populasi besar, dan peneliti tidak mungkin mempelajari semua yang ada pada populasi, misalnya karena keterbatasan dana, tenaga, dan waktu, maka peneliti dapat menggunakan sampel yang diambil dari populasi itu. Sampel pada penelitian ini adalah perangkat desa di Kecamatan Telukjambe Timur yang berjumlah 100 orang.

\section{Teknik Pengumpulan Data}

Dalam pengumpulan data ini, peneliti melaksanakan riset secara langsung pada objek penelitian untuk mendapatkan data yang diperlukan guna melengkapi data yang dibutuhkan yaitu dengan cara :

a. Angket (Questionnaire) yaitu cara pengumpulan data secara tertulis berupa sejumlah pertanyaan tertutup maupun terbuka yang diisi oleh reponden. Berdasarkan pada isian tersebut, peneliti memperoleh informasi dari responden.

b. Wawancara (Interview) yaitu metode pengumpulan data melalui pertanyaan yang diajukan secara lisan dan langsung yaitu dilakukan dengan bertatap muka.

c. Studi Pustaka Yaitu dengan menggunakan buku dan mempelajari literatur yang ada kaitannya dengan penelitian ini.

\section{Instrument Penelitian}

Instrumen penelitian adalah alat atau fasilitas yang digunakan oleh peneliti dalam mengumpulkan data penelitian agar pekerjaannya menjadi lebih mudah dan baik, dalam arti lebih cermat, lengkap sistematis sehingga lebih mudah untuk diolah. Adapun instrumen yang digunakan dalam penelitian gunakan adalah pedoman observasi, pedoman angket, serta pedoman wawancara dan dokumentasi.

\section{Pengujian Instrument Penelitian}

Dalam penelitian ini, karena penelitian ini menggunakan menggunakan pendekatan kuantitatif tentu menggunakan instrumen pengumpulan data (terutama kuesioner).Ada beberapa uji instrumen pengumpulan data, yaitu : Validitas Instrument dan Reliabilitas Instrument.

\section{Transformasi Data}

Mengingat analisis yang digunakan adalah analisis jalur, maka dipersyaratkan bahwa skala pengukuran yang dipakai sekurang-kurangnnya adalah skala interval. Karena data yang diperoleh dari instrumen penelitian adalah data ordinal, maka untuk bisa melanjutkan proses analisis jalur, data dalam bentuk skala ordinal tersebut dinaikan (ditransformasikan) terlebih dahulu ke dalam skala interval menggunakan Method of Successive Interval (MSI). Transformasi data berasal dari transform, merubah bentuk data dari bentuk data asli ke bentuk lain tanpa merubah datanya. Pada pendekatan analisa jalur seringkali digunakan tipe data ordinal. Tipe data tersebut mereflesikan peubah-peubah yang sebelumnya berasal dari suatu konsep yang sudah diubah bentuknya sehingga dapat diukur 
(Nazir, 1998 dalam buku Pedoman Penyusunan Tugas Akhir Mahasiswa, 2012). Analisa jalur membutuhkan perhitungan matematis di dalamnya. Oleh karena itu skala pengukuran data yang dibutuhkan minimal berskala interval.

\section{Uji Keabsahan Data}

Ketajaman analisis peneliti dalam menyajikan sebuah data tidak serta merta menjadikan hasil temuan peneliti sebagai data yang akurat dan memiliki tingkat kepercayaan yang tinggi. Perlu melewati pengujian data terlebih dahulu sesuai dengan prosedural yang telah ditetapkan sebagai seleksi akhir dalam menghasilkan atau memproduksi temuan baru. Oleh karena itu, sebelum melakukan publikasi hasil penelitian, peneliti terlebih dahulu harus melihat tingkat kesahihan data tersebut dengan melakukan pengecekan data melalui pengujian keabsahan data, melalui Uji Validitas Data, Uji Reliabilitas Data, Uji Normalitas Data

\section{Rancangan Analisis dan Hipotesis}

Rancangan analisis menggunakan Analisis Deskriptif dengan menggunakan analisis tabulasi data dan grafik, analisis rentang skala serta analisis verifikatif dengan menggunakan analisis korelasi, Analisis Jalur (Path Analyze), serta melakukan uji hipotesis uji t dan uji F.

\section{Hasil Penelitian}

Data dari hasil penelitian untuk variabel bebas pertama yaitu variabel kepemimpinan $\left(\mathrm{X}_{1}\right)$ yang dijaring melalui penyebaran kuesioner dengan jumlah pertanyaan sebanyak 15 butir instrument dengan penggunaan skala pilihan jawaban mulai dari 1 hingga skala lima (5 opsion). Bahwa responden paling banyak menjawab pada pernyataan cukup setuju tentang variabel kepemimpinan ini atau sekitar $24,80 \%$, dapat dilaksanakan sangat sesuai dengan baku standar yang ada ditempat bekerja. Hal ini menunjukan bahwa responden cukup setuju pelaksanaan pola kepemimpinan yang ada sekarang. Total keseluruhan dari kuesioner tentang kepemimpinan yang dibagikan kepada 100 responden menghasilkan angka sebesar 5.050 dengan rata-rata sebesar 337. Angka tersebut berada pada interval pernyataan cukup setuju. Hal ini berarti bahwa terdapat cukup setuju Aparatur Desa terhadap pola kepemimpinan atasan didalam melaksanakan kepemimpinannya untuk menggerakan kinerja atau motivasi bawahan dalam bekerja.

Bahwa responden paling banyak menjawab pada pernyataan cukup setuju tentang variabel budaya organisasi yaitu berjumlah 500 pernyataan atau sekitar 26,32\% dari total pernyataan 1.900. Artinya bahwa Aparatur Desa masih cukup setuju dalam menjalakan budaya organisasi ditempat kerjanya. Total keseluruhan dari kuesioner tentang budaya organisasi yang dibagikan kepada 100 responden menghasilkan angka sebesar 6.410 dengan rata-rata sebesar 337. Angka tersebut berada pada interval pernyataan cukup setuju. Hal ini berarti bahwa terdapat cukup setuju Aparatur Desa terhadap budaya organisasi dilingkungan tempat kerja masih sulit dilaksanakan karena pengawasan yang kurang dari pimpinan terrhadap prinsip-prinsip budaya organisasi dalam lingkungan pekerjaan.

Bahwa responden paling banyak menjawab pada pernyataan cukup setuju tentang variabel motivasi yaitu berjumlah 213 pernyataan atau sekitar 26,63\% dari 
total pernyataan 800 . Total keseluruhan dari kuesioner tentang motivasi yang dibagikan kepada 100 responden menghasilkan angka sebesar 2.708 dengan ratarata sebesar 339. Angka tersebut berada pada interval pernyataan cukup setuju. Hal ini berarti bahwa terdapat cukup setuju Aparatur Desa terhadap pola pemberian motivasi kerja yang diberikan oleh pimpinan di lingkungan tempat kerja.

Bahwa responden paling banyak menjawab pada pernyataan cukup setuju tentang variabel kinerja yaitu berjumlah 505 pernyataan atau sekitar $26,54 \%$ dari total pernyataan 1.903. Total keseluruhan dari kuesioner tentang kinerja yang dibagikan kepada 100 responden menghasilkan angka sebesar 6.390 dengan ratarata sebesar 336. Angka tersebut berada pada interval pernyataan cukup setuju. Hal ini berarti bahwa terdapat cukup setuju Aparatur Desa terhadap kinerja yang ada di lingkungan tempat kerjanya.

Analisis korelasi digunakan untuk mengetahui besaran koefisien di antara variabel bebas kepemimpinan dengan budaya organisasi. Besaran koefisien korelasi diantara variabel bebas yaitu kepemimpinan dengan budaya organisasi sebesar 0,595. Dengan demikian korelasi kepemimpinan dengan budaya organisasi memiliki tingkat korelasi yang sedang dan nilainya positif dikarenakan berada di interval koefisien nilai 0,40 - 0,599: tingkat hubungan yang kuat. (Sugiyono, 2014:184). Koefesien jalur variabel kepemimpinan $\left(\mathrm{X}_{1}\right)$ terhadap kinerja (Y) adalah sebesar 0,296. Hal ini berarti bahwa pengaruh langsung variabel kepemimpinan $\left(\mathrm{X}_{1}\right)$ terhadap kinerja $(\mathrm{Y})$ sebesar 0,296. Dengan demikian dapat diperoleh persamaan : $\mathrm{Y}=0,296 \mathrm{X}_{1}$. Koefesien jalur variabel Budaya organisasi $\left(\mathrm{X}_{2}\right)$ terhadap kinerja $(\mathrm{Y})$ sebesar 0,420. Hal ini berarti bahwa pengaruh langsung variabel Budaya organisasi $\left(\mathrm{X}_{2}\right)$ terhadap kinerja $(\mathrm{Y})$ sebesar 0,420. Dengan demikian dapat diperoleh persamaan : $\mathrm{Y}=0,420 \mathrm{X}_{1}$. Bahwa pengaruh parsial kepemimpinan terhadap kinerja sebesar 0,876 atau $87.60 \%$. Bahwa pengaruh parsial budaya organisasi terhadap kinerja sebesar 0,2504 atau 25.04\%. Bahwa pengaruh secara simultan antara kepemimpinan dan budaya organisasi terhadap kinerja sebesar 0,4120 atau 41,20\%. Dan 58,80\% merupakan pengaruh dari variabel lain. Pengaruh langsung dari motivasi terhadap kinerja yaitu $0,863 \times 0,864=0,7464$

\section{Pembahasan Hasil Penelitian}

1. Kepemimpinan memiliki 15 indikator dimana terdapat tiga indikator saja yang tidak dijawab sepenuhnya oleh 100 responden. Ketiga indikator tersebut adalah pimpinan dapat melakukan metode kerja baru kepada bawahannya, pemimpin memberikan motivasi kepada bawahannya dan pemimpin dapat memberikan beasiswa terhadap bawahan yang memiliki kinerja baik. Kelima belas indikator tersebut berada pada rentang skala 260 sampai 340 dengan kriteria cukup setuju. Artinya bahwa kepemimpinan yang dilaksanakan sekarang terdapat cukup setuju para Aparatur Desa dalam melaksanakan tugasnya. Sedangkan menurut Edy Sutisna (2011:214) bahwa kepemimpinan adalah kemampuan untuk mempengaruhi pihak lain, melalui komunikasi baik langsung maupun tidak langsung dengan maksud menggerakan orang-orang agar dengan penuh pengertian, kesadaran dan senang hati bersedia mengikuti kehendak pimpinan itu. Terdapat empat indikator yang memiliki nilai skor rendah, namun indikator pemimpin sering mengadakan diklat tentang pekerjaan memiliki nilai terendah 
diantara empat indikator tersebut. Sedngkan menurut Kartono (2009: 10), bahwa pemimpin itu diberikan wewenang atau kekuasaan, antara lain menggariskan pedoman dan petunjuk serta melakukan atau mengadakan training tentang standar baku kerja yang baik dan benar.

2. Budaya Organisasi memiliki 19 indikator yang berada pada rentang nilai 260 340. Total keseluruhan dari kuesioner tentang budaya organisasi ini yang dibagikan kepada 100 responden menghasilkan angka sebesar 6.410 dengan rata-rata sebesar 337. Dan angka tersebut berada pada interval pernyataan cukup setuju. Sementara menurut Ivancevich et.al.,2009) menyatakan bahwa Budaya organisasi melibatkan ekspektasi, nilai, dan sikap bersama, hal tersebut memberikan pengaruh pada individu, kelompok, dan proses organisasi. Hal ini berarti bahwa terdapat keragu-raguanan Aparatur Desa terhadap pola pelaksanaan Budaya Organisasi di setiap kantor desa Kecamatan Telukjambe Timur. Responden beranggapan bahwa pelaksanaan budaya organisasi haruslah sesuai dengan standar atau prinsip-prinsip baku tentang pelaksanaan budaya organisasi dalam lingkungan pekerjaan.

3. Motivasi memiliki 8 indikator yang berada pada interval $260-340$ dengan kriteria cukup setuju. Artinya bahwa aparatur desa saat ini belum bisa merasakan adanya motivasi yang dilakukan oleh pimpinannya dalam upaya peningkatan kinerja, dimana pemberian motivasi tersebut bisa berupa penghargaan ataupun lainnya. Hanya terdapat tiga indikator saja menyatakan setuju akan motivasi tersebut. Sementara menurut Hasan Sadilli (2008) motivasi adalah sesuatu yang dapat merangsang atau mendorong keinginan seseorang untuk giat dan antusias guna mencapai hasil yang optimal dalambekerja.Dengan meningkatnya motivasi karyawan, akan sangat mudah bagi perusahaan dalam upaya pemenuhan target atau sasaran yang telah ditentukan sebelumnya. Dan hasil yang akan diraihpun akan semakin sesuai dengan harapan yang diinginkan. Hal sesuai apa yang dikatakan oleh Samsudin Sadili (2008:281) bahwa Motivasi adalah proses mempengaruhi atau mendorong dari luar terhadap seseorang atau kelompok kerja agar mereka mau melaksanakan sesuatu yang telah ditetapkan.

4. Kinerja memiliki 19 indikator yang berada pada skala nilai 260 - 340 dengan kriteria cukup setuju terhadap peningkatan kinerja, artinya bahwa pola kepemimpinan dan pelaksanaan budaya organisasi yang dilakukan sekarang ini oleh pihak kecamatan Telukjambe Timur masih kurang baik dilakukan sesuai dengan prosedur yang ada dan sudah ditetapkan oleh pihak Pemerintah Daerah Kabupaten Karawang. Sedangkan menurut Sudjono (2005) kinerja merupakan prestasi kerja yakni perbandingan antara hasil kerja yang secara nyata dengan standar kerja yang ditetapkan dalam melaksanakan tugasnya sebagai pegawai, dengan indikator pengukuran kinerja. Sementara kinerja yang terjadi pada Aparatur Desa Kecamatan Telukjambe Timur belum menunjukan peningkatan. Dan itu berarti bahwa pihak Kecamatan Telukjambe Timur wajib memperbaiki hal-hal terkait upaya dalam meningkatkan kinerja Aparatur Desa Kecamatan Telukjambe Timur. Dan bila ini terus dibiarkan, maka apa yang diharapkan oleh pihak Kecamatan terkait capaian target tak akan terwujud karena menurunnya kinerja aparatur Desa yang terjadi saat ini di Kecamatan telukjambe Timur kabupaten Karawang. 


\section{Pembahasan Verifikatif}

1. Besaran koefesien korelasi antara variabel kepemimpinan dengan budaya organisasi yaitu sebesar 0,595. Dengan demikian korelasi kepemimpinan dengan budaya organisasi memiliki tingkat korelasi yang sedang dan nilainya positif dikarenakanberada di interval koefisien nilai 0,40-0,599 : Korelasi sedang (Sugiyono, 2014:184).

2. Kepemimpinan berpengaruh signifikan terhadap motivasi sebesar $16,16 \%$ dan tingkat signifikansi sebesar 0,003. Dimana 0,003 lebih kecil dari 0,05. Hal ini berarti kepemimpinan berpengaruh signifikan terhadap motivasi kerja Aparatur Desa Kecamatan Telukjambe Timur Kabupaten Karawang. Hasil penelitian ini didukung oleh penelitian Sahril (2015) dimana hasilnya adalah peran kepemimpinan dan motivasi baik parsial maupun besama-sama berpengaruh terhadap kinerja pegawai negeri sipil pada Kantor Satuan Polisi Pamong Praja Kabupaten Karawang.

Dengan adanya pola kepemimpinan atasan yang baik dan benar, maka Aparatur Desa dalam menjalankan pekerjaannya serta mengatasi kesulitankesuliatan akan semakin baik dan akan semakin giat bekerja karena kenyamanan komunikasi dengan atasan/pimpinan. Dengan semakin baiknya pola kepemimpinan atau kinerja pimpinan dalam memimpin bawahannya secara adil dan bijak maka akan semakin baik pula pola kerja Aparatur Desa karena merasa termotivasi dengan pola kepemimpinan yang dilakukan oleh atasannya dan akan segan serta menghormati yang pada akhirnya akan melakukan pekerjaan dengan maksimal.

Kepemimpinan adalah upaya mempengaruhi banyak orang melalui komunikasi untuk mencapai tujuan, cara mempengaruhi orang dengan petunjuk atau perintah, tindakan yang menyebabkan orang lain bertindak atau merespons dan menimbulkan perubahan positif, kekuatan dinamis penting yang memotivasi dan mengkoordinasikan organisasi dalam rangka mencapai tujuan, kemampuan untuk menciptakan rasa percaya diri dan dukungan diantara bawahan agar tujuan organisasional dapat tercapai. Kepemimpinan merupakan faktor pendorong karyawan untuk bekerja lebih baik dan mampu meningkatkan semangat karyawan.

Berdasarkan nilai perhitungan analisis jalur pengaruh yang ditimbulkan variabel kepemimpinan terhadap motivasi karyawan secara langsung meskipun nilainya sedang yaitu sebesar 0,2960 atau $29,60 \%$ (Sugiyono:2014,184). Pada penelitian ini terlihat ada pengaruh secara langsung yang diberikan faktor kepemimpinan terhadap motivasi Aparatur Desa Kecamatan Telukjambe Timur Kabupaten Karawang. Kepemimpinan yang dipersepsikan secara langsung mempunyai efek positif terhadap motivasi secara keseluruhan. Hal itu menunjukkan bahwa adanya pola kepemimpinan yang adil serta bijak, maka akan mampu memberikan motivasi Aparatur Desa dalam upaya mencapai target yang telah ditentukan oleh pimpinan. Komuniasi yang baik serta responsip yang cepat terhadap keluh kesah Aparatur Desa atau bawahan akan membawa efek yang sangat besar terhadap sisi emosional Aparatur Desa itu sendiri yang pada akhirnya mereka akan mampu bekerja sesuai dengan perintah atasannya dalam upaya mewujudkan target yang telah ditetapkan.

3. Pelaksanaan budaya organisasi berpengaruh secara signifikan terhadap motivasi kerja Aparatur Desa dalam bekerja. Hal tersebut dapat dilihat dari 
hasil signifikansi sebesar 25,04\% dan tingkat signifikan sebesar 0,000. Dimana 0,00 lebih kecil dari 0,05 . Hal ini berarti budaya organisasi berpengaruh signifikan terhadap motivasi kerja Aparatur Desa Kecamatan Telukjambe Timur Kabupaten Karawang. Dengan adanya pelaksanaan budaya organisasi yang baik yang sesuai dengan ketentuan baku Pemerintah Daerah Kabupaten Karawang, ternyata membuat Aparatur Desa merasa termotivasi dan mampu memberikan semangat kerja yang pada akhirnya akan menimbulkan atau memberikan efek pada kinerja karyawan sehingga target yang dibebani kepada Aparatur Desa akan mampu dilaksanakan dengan baik.

4. Pengaruh secara simultan sebesar 0,4120 atau 41,20\%. Artinya bahwa kontribusi variabel kepemimpinan dan budaya organisasi terhadap motivasi serta kinerja Aparatur Desa Kecamatan Telukjambe Timur Kabupaten Karawang sebesar $41,20 \%$, sedangkan sisanya sebesar 58,80\% dipengaruhi faktor lain yang tidak diteliti dalam penelitian ini.

5. Motivasi berpengaruh signifikan terhadap peningkatan kinerja sebesar 0,7464 atau 74,64\% dan tingkat signifikansi sebesar 0,00 dimana 0,00 lebih kecil dari 0,05 . Hal ini berarti motivasi berpengaruh signifikan terhadap peningkatan kinerja Aparatur Desa Kecamatan Telukjambe Timur Kabupaten Karawang. Motivasi berpengaruh positif terhadap peningkatan kinerja Aparatur Desa Kecamatan Telukjambe Timur Kabupaten Karawang. Berarti semakin tinggi motivasi Aparatur Desa atas suatu pekerjaan maka akan semakin meningkatkan kinerjanya. Demikian juga sebaliknya, semakin rendah motivasi Aparatur Desa maka akan rendah juga kualitas atau hasil kinerja yang diinginkan.

Motivasi merupakan hasil sejumlah proses yang bersifat internal atau eksternal bagi seorang individu, yang menyebabkan timbulnya sikap entusiasme dan persistensi dalam hal melaksanakan kegiatan-kegiatan tertentu. Karyawan yang mempunyai motivasi yang tinggi maka akan lebih mudah mendapatkan peningkatan kinerja yang diinginkan. Karena dengan adanya motivasi tersebut akan menimbulkan dorongan untuk bekerja lebih giat sehingga hasilnya optimal. Dengan hasil yang optimal maka peningkatan kinerja yang diharapkan akan lebih meningkat. Hasil penelitian ini terlihat ada pengaruh tidak langsung dan langsung faktor motivasi terhadap peningkatan kinerja Aparatur Desa Kecamatan Telukjambe Timur Kabupaten Karawang. Pengaruh tidak langsung melalui motivasi karyawan. Hal itu menunjukkan persepsi terhadap motivasi yang tinggi akan menimbulkan motivasi sehingga secara tidak langsung akan menyebabkan Aparatur Desa melakukan pekerjaan secara optimal. Apabila hasil kerja optimal maka dapat meningkatkan kinerja para Aparatur Desa Kecamatan Telukjambe Timur Kabupaten Karawang. Motivasi para Aparatur Desa Kecamatan Telukjambe Timur Kabupaten Karawang yang dipersepsikan secara langsung berpengaruh positif terhadap motivasi Aparatur Desa secara keseluruhan, demikian juga motivasi yang dirasakan berpengaruh positif terhadap prestasi kerja Aparatur Desa Kecamatan Telukjambe Timur Kabupaten Karawang.

Hasil ini diukung oleh hasil penelitian Anoki Herdian Dito (2010) dalam penelitannya yang berjudul Pengaruh Kompensasi Terhadap Kinerja Karyawan dengan motivasi sebagai variabel intervening PT. Slamet Langgeng Purbalingga. Dimana hasilnya adalah Berdasarkan uji-t yang dilakukan dan hasil analisis regresi linier 1 di atas dapat diketahui bahwa Kompensasi 
berpengaruh positif dan signifikan terhadap Motivasi dan pada hasil analisis regresi linier 2 diketahui bahwa Kompensasi dan Motivasi berpengaruh positif dan signifikan terhadap Kinerja. Dan berdasarkan hasil dua analisis regresi linier di atas dapat dilakukan uji mediasi (intervening) sehingga diketahui bahwa varibel motivasi mampu menjadi variable intervening oleh karena perhitungan standardized coeffients untuk pengaruh tidak langsung kompensasi terhadap kinerja melalui motivasi kerja lebih besar dibanding pengaruh secara langsung kompensasi terhadap kinerja. Dan juga hasil penelitian Wijayanti Dwi Wahyu (2012) bahwa motivasi memiliki pengaruh sebesar 0,151 terhadap kinerja karyawan terdapat pengaruh positif tidak signifikan antara motivasi terhadap kinerja karyawan dimana $\mathrm{t}_{\text {hitung }} 0,915<\mathrm{t}_{\text {tabel }} 1,701$ dan taraf signifikan $0,386<0,05$ maka Ho ditolak atau Ha diterima. Sedangkan berdasarkan uji koefisien determinasi menunjukkan kepemimpinan dan motivasi kerja secara bersama-sama berpengaruh terhadap variabel kinerja karyawan sebesar 67,4\% .

\section{Simpulan}

Berdasarkan hasil penelitian yang dilakukan pada Aparatur Desa Kecamatan Telukjambe Timur Kabupaten Karawang dapat disimpulkan sebagai berikut :

1. Kepemimpinan ada pada kriteria jawaban cukup setuju, hal ini dibuktikan dengan nilai skor sebesar 5.050 dengan nilai rata-rata 337. Ini berarti bahwa terdapat cukup setuju Apartaur Desa terhadap pola pelaksanaan kepemimpinan yang ada. Terdapat tiga indikator yang memiliki nilai rendah, namun indikator pemimpin sering mengadakan diklat tentang pekerjaan memilki nilai skor terendah.

2. Budaya organisasi ada pada kriteria cukup setuju, hal ini dibuktikan dengan nilai skor sebesar 6.410 dengan nilai rata-rata 337. Hal ini berarti bahwa terdapat cukup setuju Aparatur Desa terhadap budaya organisasi dilingkungan tempat kerja masih sulit dilaksanakan karena pengawasan yang kurang dari pimpinan terrhadap prinsip-prinsip budaya organisasi dalam lingkungan pekerjaan. Indikator terendah ada pada indikator dalam melakukan pekerjaan, diperlukan ide atau tindakan yang inovatif.

3. Motivasi ada pada kriteria cukup setuju, hal ini dibuktikan dengan nilai skor sebesar 2.708 dengan nilai rata-rata 339. Hal ini berarti bahwa terdapat cukup setuju Aparatur Desa terhadap motivasi kerja yang diberikan oleh pimpinan di lingkungan tempat kerja masih kurang. Dari ketiga indikator tersebut nilai terendah ada pada indikator disiplin kerja menjadi salah satu penilaian bekerja bagi setiap petugas dengan nilai skor 326 .

4. Kinerja ada pada kriteria cukup setuju, hal ini dibuktikan dengan nilai skor sebesar 6.390 dengan nilai rata-rata 336. Hal ini berarti bahwa terdapat cukup setuju Aparatur Desa terhadap kinerja yang ada di lingkungan tempat kerjanya.Terdapat satu indikator dengan nilai terendah yaitu indikator saya selalu bangga dengan pekerjaan saya dengan nilai skor 325 .

5. Besaran nilai koefesien korelasi antara variabel kepemimpinan dengan budaya organisasi yaitu sebesar 0,595 Dengan demikian korelasi kepemimpinan dengan budaya organisasi memiliki tingkat korelasi yang sedang dan nilainya positif dikarenakan berada di interval koefisien nilai 0,40-0,599 : Korelasi sedang (Sugiyono, 2014:184). Hal ini menunjukan bahwa kepemimpinan 
dengan budaya organisasi berperan dalam meningkatkan kinerja Aparatur Desa Kecamatan Telukjambe Timur Kabupaten Karawang.

6. Besaran pengaruh kepemimpinan dan budaya organisasi terhadap motivasi diperoleh masing-masing 0,1616 atau $16,16 \%$ dan 0,2504 atau 25,04\%. Dari hasil yang diperoleh menunjukan bahwa budaya organisasi lebih dominan memberikan kontribusi terhadap motivasi karyawan dibandingkan pemberian kepemimpinan $(25,04 \%>16,16 \%)$.

7. Besaran pengaruh kepemimpinan dan budaya organisasi terhadap kinerja melalui motivasi 0,4120 atau 41,20\%. Artinya bahwa kontribusi variabel kepemimpinan dan budaya organisasi terhadap motivasi serta kinerja Aparatur Desa sebesar $41,20 \%$, sedangkan sisanya sebesar $58,80 \%$ dipengaruhi faktor lain yang tidak diteliti dalam penelitian ini. Dan berdasarkan hasil hipotesis yang diperoleh dapat disimpulkan bahwa kepemimpinan dan budaya organisasi berkontribusi secara simultan dan signifikan terhadap kinerja melalui peningkatan motivasi Aparatur Desa Kecamatan Telukjambe Timur Kabupaten Karawang dapat diterima.

8. Pengaruh motivasi terhadap kinerja memiliki pengaruh sebesar 0,7464 atau 74,64\% artinya bahwa peningkatan kinerja melalui motivasi apartaur desa pada Kecamatan Telukjambe Timur Kabupaten Karawang dapat dibuktikan sebesar $74,64 \%$. Hal ini berarti motivasi berpengaruh signifikan terhadap peningkatan kinerja aparatur desa pada kecamatan Telukjambe Timur kabupaten Karawang. Motivasi berpengaruh positif terhadap peningkatan kinerja aparatur desa pada kecamatan Telukjambe Timur kabupaten Karawang. Berarti semakin tinggi motivasi aparatur desa atas suatu pekerjaan maka akan semakin meningkatkan kinerjanya. Demikian juga sebaliknya, semakin rendah motivasi aparatur desa kinerja yang diinginkan

\section{Saran}

Berdasarkan hasil pembahasan dan kesimpulan, maka disarankan sebagai berikut :

1. Sebaiknya pemimpin mengadakan diklat atau pelatihan kepada bawahannya mengenai pengenalan pekerjaan dan atau menginformasikan tentang job descripton masing-masing aparatur Desa agar bisa tercipta koordinasi yang baik antara pimpinan dan bawahan. Dan agar tetap selalu memberikan penghargaan terhadap Aparatur Desa yang memilki prestasi kerja baik terus dilaksanakan demi menghasilkan hasil kerja dengan kualitas tinggi.

2. Dan bagi para Aparatur Desa, hendaknya dalam melakukan pekerjaan agar bisa lebih mandiri dan penuh kreasi serta inovasi agar pekerjaan bisa dihasilkan dengan baik. Serta diharapkan agar bisa mengambil sebuah tindakan tegas atau berani mengambil resiko dalam melakukan pekerjaannya jika memang hal tersebut harus dilakukan secepatnya tanpa harus koordinasi terlebih dahulu, karena koordinasi bisa dilakukan setelah pengambilan keputusan atau tindakan dan harus siap bertanggung jawab terhadap keputusannya tersebut. Penyampaian permasalahan dengan terbuka untuk mencari solusi atau pemecahan terhadap permasalahan tersebut hendaknya tetap dilakukan oleh para Aparatur Desa agar permasalahan yang ada tidak berlarut-larut mengingat Aparatur Desa adalah abdi dari Warga Desa dan menghindari terhambatnya pelayanan warga. 
3. Sebaiknya para Aparatur Desa lebih meningkatkan kembali sikap disiplin kerja karena disiplin kerja merupakan bagian dari penilaian kerja setiap Aparatur Desa. Tanpa adanya disiplin dalam bekerja maka hasil yang akan diperoleh tentunya akan mengecewakan pimpinan secara khusus dan pekerjaan secara umumnya. Dan dikhawatirkan akan berdampak pada terhambatnya pelayanan terhadap masyarakat di desa masing-masing. Bagi pimpinan dalam hal ini pihak Kecamatan tetap memberikan bonus kepada para Aparatur Desa yang mampu menyelesaikan pekerjaan sesuai waktu yang telah ditentukan atau yang sudah ditargetkan secara bersama-sama antara pihak kecamatan dengan para Aparatur Desa.

4. Sebaiknya para Aparatur Desa bisa memilki atau merasakan bahwa pekerjaan yang dikerjakannya tersebut adalah untuk diri sendiri, sebab dengan merasa memilki maka hasil yang akan diperolehpun maksimal dan tidak akan mengecewakan atasan dalam hal ini pihak Kecamatan. Dan tetap mempertahankan cara kerja agar memberikan hasil pekerjaan secara maksimal sesuai dengan jam kerja yang telah ditetapkan serta tetap menjalin koordinasi demi terciptanya kerjasama yang baik dalam melakukan pekerjaan antara Aparatur Desa dengan Kecamatan Telukjambe Timur yang dalam hal ini adalah pimpinan.

5. Penelitian lebih lanjut tentang variabel lainnya yang mempengaruhi variabel kinerja melalui motivasi kerja pegawai Aparatur Desa Kecamatan Telukjambe Timur Kabupaten Karawang yang tidak diteliti dalam penelitian ini sehingga diharapkan fungsi dan sistem manajemen dapat berjalan lebih optimal.

\section{Daftar Pustaka}

ArfinMurti, (2012). "MenciptakanSumberDayaManusia Yang HandalDengan Training, Coaching dan Motivation”. Sidoarjo :LaskarAksara.

Arikunto, S. (2010).Prosedurpenelitian :SuatuPendekatanPraktik. (EdisiRevisi).Jakarta :RinekaCipta

Amirullah\&HarisBudiyono. 2004. PengantarManajemen. Yogyakarta :Grahallmu.

Anoraga, Pandji.2000. PsikologiKepemimpinan. Jakarta: RinekaCipta.

As'ad, M. (2003), Psikologi Industri: Seri Sumber Daya Manusia, Liberty, Jogjakarta.

-----------. 2004. Psikologi Industri. Yogyakarta: Liberty

Burhan Bungin, MetodologiPenelitianKuantitatif, Jakarta: Prenada Media, 2005, hlm. 75

Bangun, Wilson. (2012). Manajemen Sumber Daya Manusia. Jakarta : Penerbit Erlangga

Dubrin, Andrew. Leadership (Terjemahan). Edisi Kedua. Jakarta: Prenada Media,2006

Ghozali, Imam. 2006. AplikasiAnalisis Multivariate dengan Program SPSS. Semarang: BP UNDIP.

Hasibuan, S.P Malayu, (2014). “ManajemenSumberDayaManusia”.EdisiRevisi, Jakarta :BumiAksara.

Heidjrachman, 2002. Manajemen Personalia, Cetakan Sepuluh. Penerbit : BPFE, Yogyakarta. 
Gibson, James L, et.al. 2000. Organisasi: Perilaku, Struktur, Proses. Edisi Kelima. Alih Bahasa Djoerban Wahid Jakarta: Erlangga

Hani Handoko, 2001. ManajemenPersonaliadanSumberDayaManusia ,edisi 2, Yogyakarta: BPFE.

“ManajemenPersonaliadanSumberDayaManusia”.CetakanKe 16, Yogyakarta.

Indrawijaya, Adam Ibrahim. (2000). Perilaku Organisasi. Jakarta : Sinar Baru Algesindo.

Koesmono, H. Teman (2006) Pengaruh Budaya Organisasi Terhadap Motivasi dan Kepuasan Kerja serta Kinerja Karyawan Pada Sub Sektor Industri Pengolahan Kayu Skala Menengah Di Jawa Timur. JURNAL ANAJEMEN \& KEWIRAUSAHAAN, VOL. 7, NO. 2, SEPTEMBER 2005: 171-188.

Muhammad, Arni, 2007. Komunikasi Organisasi. Jakarta : Bumi Aksara

MangkunegaraPrabu Anwar, (2008). “Manajemen SDM Perusahaan”.Edisi Dari TeoriKePraktik, bandung :Alfabeta.

Mathis, Robert L dan Jackson. 2006. ManajemenSumberDayaManusia. Jakarta: SalembaEmpat

Martoyo, Susilo. 2007. ManajemenSumberdayaManusia. Edisi 5.BPFE. Yogyakarta

Moeheriono. 2012. "Pengukuran Kinerja Berbasis Kompetensi”. Jakarta: Raja Grafindo Persada

Ndraha, Taliziduhu, 2003. Budaya Organisasi. Jakarta : Rineka Cipta

Notoatmojo, Soekidjo, (2009). “PengembanganSumberDayaManusia”.Jakarta : PT. RinekaCipta.

Nitisemito, Alex. 2009. ManajemenPersonalia. Jakarta: Ghalia Indonesia

RidwandanKuncoro, (2007).“Cara MenggunakandanmemaknaiAnalisisalur (Path Analysis)”.Bandung :Alfabeta.

Rivai, Veithzal. 2005. ManajemenSumberDayaManusiauntukPerusahaan :dariTeorikePraktik. Jakarta : PT Raja GrafindoPersada.

Robbins, Stephen, P. 2002. Prinsip-prinsip Perilaku Organisasi. Jakarta :Erlangga.

Richard L. Daft. 2010. Era BaruManajemen. Buku 1 dan2.Jakarta :SalembaEmpat

Pace, R. Wayne dan Don F. Faules.1998.Komunikasi Organisasi : Strategi meningkatkan Kinerja Perusahaan.RemajaRosdaKarya. Bandung

Poerwanto, 2008. Budaya Perusahaan. Yogyakarta : Pustaka Pelajar

Priyanto, Duwi, (2008). “MandiriBelajarSPSS”.Yogyakarta :Mediakom.

Purwanto,M. Ngalim, 2000. AdministrasidanSupervisiPendidikan, Jakarta: RemajaRosdakarya.

Simamora, Henry. (2004). “ManajemenSumberDayaManusia”.Yogyakarta : STIE YKPN.

SingarimbunMasridanEfendiSofian, (2006). “MetodePenelitianSurvei”.Jakarta : LP3ES.

Sutrisno, Edy. 2010. ManajemenSumberDayaManusia. Edisi 1.CetakanKedua.Prenada Media Group. Jakarta 
Sugiyono, (2011). “MetodePenelitianKuantitatif, Kualitatifdan R\&D”. Cetakan ke-14. CV. Alfabeta, Bandung.

Santoso, Singgih. (2004). "SPSS Versi 12". Jakarta :GramediaPustakaUtama.

Simamora, Henry. (2006). “ManajemenSumberDayaManusia”.Yogyakarta :

SekolahTinggillmuEkonomi YKPN.

Siagian, Sondang P. 2001. ManajemenSumberDayaManusia.Jakarta :Bumiaksara.

Sugiyono, (2009). “MetodologiPenelitianBisnis".Cetakan 13. CV. Alfabeta, Bandung.

Sinungan Muchdarsyah, 2008. Produktivitas Apa dan Bagaimana. Jakarta: PT Bumi Aksara

Stonner, James, A.F. 2002. Manajemen.Edisi II. Prenhalindo ; Jakarta

Tika, Moh. Pabundu.(2006). "MetodologiRisetBisnis”. Jakarta: PT. BumiAksara.

Terry, R George.(2005). “Dasar-dasarManajemen”.CetakanKe Sembilan, Jakarta : PT. BumiAksara.

Wibowo, (2005). “ManajemenKinerja”.Jakarta : PT. Raja GrafindoPersada.

---(2010). “ManajemenKinerja”.Yogyakarta :GrahaIlmu.

Wilson Bangun, ManajemenSumberDayaManusia, Jakarta: Erlangga, 2012, hlm. 210-211

Winardi, 2007. Teori Organisasi dan Pengorganisasian. Divisi Buku Perguruan Tinggi

Wahjosumidjo. 1991. Kepemimpinan yang Efektif. Yogyakarta: BalaiPustaka. 